\title{
Estimation of virus-neutralizing antibody in microplates
}

\author{
P. J. PEAD AND A. HOLLEY \\ From the Public Health Laboratory, St Mary's General Hospital, Portsmouth
}

SYNOPSIS A simple and rapid method for the titration of virus-neutralizing antibody is described. The micro-apparatus and reagents are readily available from commercial sources. Results are included from selected cases which illustrate various conditions of immune status and response.

Virus-neutralizing antibodies are seldom estimated in routine diagnostic laboratories because methods involving replicate series of tubed cell monolayers are so demanding of time and materials. Simplified methods for performing neutralization tests have been described, but these were generally developed for specific purposes and have required various forms of specialized apparatus.

One of the earliest techniques was introduced by Melnick and Opton (1956) for the assay of polio antibodies in monkey kidney cells. Plastic panels were used and results were determined by the observation of metabolic inhibition. When microtitration apparatus became commercially available, neutralization tests were performed in plastic microplates. Sever (1961) described a system for measuring polio antibodies, whilst Schmidt, Lennette, and Hanahoe (1966) used a micro-test for the detection of reovirus antibodies in the sera of laboratory animals. Both of these methods also depended upon the metabolic inhibitory action of virus upon the cell cultures. Moreau and Furesz (1967) employed a micro-technique for the titration of measles antibodies. The extent of cytopathic effect produced by the virus was observed microscopically.

Most of the methods involved the rather inconvenient practice of sealing the microplate wells with mineral oil, followed by incubation in humidified cabinets, gassed with a mixture of carbon dioxide and air. These precautions were required to enable bicarbonate buffers to maintain the culture media at a suitable $\boldsymbol{p H}$ for cell growth. Another disadvantage of micro-testing has been the necessary chemical treatment of microplates to remove cytotoxic factors.

The aim of this paper is to present a simplified micro-technique for the estimation of virus-neutra-

Received for publication 24 October 1972. lizing antibodies. No specialized apparatus other than the micro-titration equipment is necessary and the method is, therefore, suitable for use in any virology laboratory. The same method may be used for a number of different viruses and cell culture lines.

\section{Materials and Methods}

\section{CELL CULTURES}

Hep 2 cells were used for all enterovirus titrations and subsequent serum neutralization tests. Estimations of antibody to Herpesvirus hominis were made using either human embryonic lung fibroblasts or WI-38 cells. Monkey kidney and HeLa cells were also cultured successfully in the microplates.

CELl CUlture MEdia

Eagles minimal essential medium was used for the culture of Hep 2 and HeLa cells. Human embryonic lung fibroblasts and WI-38 cells were grown in Eagles basal medium. Both of these media were supplemented with calf serum at a concentration of $10 \%$. Medium 199 , containing $5 \%$ calf serum, was used for the growth of monkey kidney cells.

All cell culture media were buffered with a $20 \mathrm{mM}$ solution of N-2-hydroxyethylpiperazine- $\mathrm{N}$-2-ethanesulphonic acid (HEPES), eliminating the need for gassed incubation. Preliminary experiments with bicarbonate-buffered media gave less satisfactory results.

\section{MICROPLATES}

Sterile tissue culture grade microplates with flat bottomed wells (Flow Laboratories Ltd) were used. No pretreatment of the microplates was found to be necessary. Routine grade microplates, pretreated with alcohol and rinsed with distilled water, proved 
less reliable, particularly for the culture of embryonic lung cells.

\section{MICRODROPPERS}

Disposable microdroppers delivering a unit volume of $0.025 \mathrm{ml}$ (Flow Laboratories Ltd) were found to be suitable for use direct from the manufacturer's carton. No procedures for sterilizing the microdroppers were employed. Minimal immersion of the dropper tip whilst filling the microdropper eliminated subsequent delivery of drops in excess of the standard volume.

\section{MICRODILUTERS}

A multidiluter handle (Flow Laboratories Ltd), capable of holding up to $120.025 \mathrm{ml}$ microdiluters, was used for serum dilution. Within a single microplate, multiple titrations of either a single serum against more than one antigen, or of several different sera against a single antigen, were performed with equal ease. The microdiluters were cleaned and sterilized by flaming to red heat.

\section{PRELIMINARY VIRUS TITRATIONS}

Suspensions of fresh virus were obtained by passage in cell culture. Serial 10 -fold dilutions of the virus were prepared in tubes using syringe pipettes. Several wells in the microplate were inoculated by microdropper with 1 volume from each virus dilution, beginning with the weakest concentration. Although it was found that only two wells per dilution gave sufficiently consistent endpoints, a minimum of four wells per dilution was considered desirable for statistical calculation. One volume of serum-free tissue culture medium was added to each well in place of patient's serum. A suspension of approximately 500000 cells per $\mathrm{ml}$ was prepared and 1 volume added to each well by microdropper. Control wells containing 2 volumes of tissue culture medium and 1 volume of cell suspension were included. The microplates were sealed with clear adhesive tape of 3 in. width to prevent evaporation.

The cultures were incubated at $37^{\circ} \mathrm{C}$ and observed daily with an inverted microscope. Cells were easily seen on the base of the wells and levels of $50 \%$ cytopathic effect (TCD 50) recorded. The control wells were checked to ensure that the virus-free cells had not deteriorated. When the TCD 50 dose of virus was finally determined, a note of the incubation time was also recorded. Most viruses yielded suitable TCD 50 endpoints at about 48 hours. The virus was stored in $2 \mathrm{ml}$ aliquots at $-70^{\circ} \mathrm{C}$.

SERUM NEUTRALIZATION TITRATION Initial 1 in 5 dilutions of sera were made in a separate microplate by adding 1 drop of serum to 4 drops of tissue culture medium in each appropriate well. A complete row of wells would include either several different sera for titration against one virus, or preparations of one serum to be titrated against several viruses. Test microplates were labelled and 1 volume of tissue culture medium was added to each well. Using the multidiluter, 1 volume of 1 in 5 dilution was transferred to the first row of the test microplate and serial doubling dilutions were made from 1 in 10 to 1 in 160 .

For each set of titrations one aliquot of virus suspension was thawed and diluted to give a standard concentration of 100 TCD 50: any of this working suspension not used was discarded, so that for each batch of tests fresh virus of standard potency was used. One volume of virus suspension was added to the appropriate wells in the test microplate. Control titrations of virus suspension at dilutions expected to contain $100,10,1,0.1$ and 0.01 TCD 50 doses, plus a normal cell control were included. The microplates were then left at room temperature for 30 minutes. One volume of cell suspension at 500000 cells per $\mathrm{ml}$ was added to all wells containing tests or controls. After sealing, the microplates were incubated at $37^{\circ} \mathrm{C}$.

During incubation, daily readings of the control virus titrations were made until the extent of cytopathic effect matched that demonstrated in the preliminary virus titration. Generally, the incubation times were comparable. At this stage the serum neutralization tests were read and the reciprocals of the dilutions of serum causing $50 \%$ inhibition of cytopathic effect recorded as the neutralizing antibody titres. Inhibition was more easily discernible when readings were commenced at the weakest concentration of each serum.

\section{Results}

The inverted microscope was found to be most suitable for observing cell cultures, but a normal bench microscope could be used for inspecting inverted microplates, providing the wells had been adequately sealed. Inevitably, the use of microdiluters resulted in partial scratching on the flat base of microplate wells, but this did not inhibit cell growth significantly. When HEPES-buffered medium was used, inhibition of cell metabolism by virus caused no observable change in the $p \mathrm{H}$ of the medium. Most tests were readable after 48 hours' incubation, and normal monolayers had not produced a colour change in the tissue culture medium at this stage.

To date, we have titrated 57 sera against several viruses in microplates. Selection of virus types depended on clinical symptoms or suggestive complement-fixation results. Several cases are 
shown in Tables I, II, and III. All neutralization titres represent antibody measured against 100 TCD 50 of virus. Control batch titrations on virus potency were very consistent.

The Coxsackie B5 antigen, used in complement fixation, was prepared by infecting monkey kidney cells with Coxsackie B5 virus. The antigen generally crossreacts with antibodies to all Coxsackie B types and also to some Echovirus types, although, as Table I shows, this cannot always be relied upon.

Neutralizing antibody titres usually remain demonstrable for long periods of time following vaccination or natural infection, whilst complementfixing antibodies soon decay. Patient M.W. had received several doses of vaccine in recent years. Patient N.A., a 5-month-old girl, had been given a second dose only one month before the first serum was taken. Poliovirus, Sabin type I, was isolated from her stools. The second specimen of serum was received six months after vaccination.
Neutralizing antibody titre rises were not demonstrable in paired sera from patients M.P. and J.M., although serological diagnosis was established in both cases by complement fixation. The second sera were taken only eight days after the first specimens. Longer intervals of 20 and 30 days between the sera of patients M.G. and M.S., respectively, had allowed measurable titres of neutralizing antibody to be formed.

In a survey of cerebrospinal fluids from 93 symptomless psychiatric cases, one patient was found to have neutralizing antibody to Herpesvirus hominis. Examination of his cerebrospinal fluid and sera by complement fixation also yielded high antibody titres.

\section{Discussion}

Although occasions arise when the titration of neutralizing antibodies may yield relevant informa-

\begin{tabular}{|c|c|c|c|c|c|c|c|c|}
\hline \multirow[t]{2}{*}{ Patient } & \multirow[t]{2}{*}{ Date } & \multicolumn{6}{|c|}{ Neutralizing Antibody Titres against Coxsackie Virus } & \multirow{2}{*}{$\begin{array}{l}\text { Complement-fixing Antibody } \\
\text { Titres against Coxsackie BS } \\
\text { Antigen }\end{array}$} \\
\hline & & $B I$ & $\boldsymbol{B 2}$ & B3 & $B 4$ & $B 5$ & $B 6$ & \\
\hline $\begin{array}{l}\text { E.C. } \\
\text { E.C. } \\
\text { J.B. } \\
\text { J.B. } \\
\text { A.R. } \\
\text { A.R. }\end{array}$ & $\begin{array}{l}16.7 .71 \\
26.7 .71 \\
22.6 .71 \\
30.7 .71 \\
15.12 .71 \\
29.12 .71\end{array}$ & $\begin{array}{r}<10 \\
10 \\
160 \\
320 \\
<10 \\
<10\end{array}$ & $\begin{array}{l}<10 \\
<10 \\
320 \\
640 \\
<10 \\
<10\end{array}$ & $\begin{array}{r}<10 \\
640 \\
40 \\
320 \\
<10 \\
<10\end{array}$ & $\begin{array}{r}40 \\
80 \\
80 \\
160 \\
80 \\
80\end{array}$ & $\begin{array}{r}<10 \\
<10 \\
40 \\
80 \\
<10 \\
<10\end{array}$ & $\begin{array}{r}<10 \\
<10 \\
<10 \\
10 \\
<10 \\
<10\end{array}$ & $\begin{array}{c}80 \\
320+ \\
80 \\
320+ \\
<10 \\
<10\end{array}$ \\
\hline
\end{tabular}

Table I Antibodies in three patients to Coxsackie B virus

\begin{tabular}{|c|c|c|c|c|c|c|c|}
\hline \multirow[t]{2}{*}{ Patient } & \multirow[t]{2}{*}{ Date } & \multicolumn{3}{|c|}{ Neutralizing Antibody Titres against Poliovirus } & \multicolumn{3}{|c|}{ Complement-fixing Antibody Titres against Poliovirus } \\
\hline & & $P I$ & $P 2$ & $P 3$ & $P I$ & $P 2$ & $P 3$ \\
\hline $\begin{array}{l}\text { M.W. } \\
\text { M.W. } \\
\text { V.G. } \\
\text { V.G. } \\
\text { N.A. } \\
\text { N.A. } \\
\text { G.W. } \\
\text { C.C. }\end{array}$ & $\begin{array}{c}6.4 .71 \\
13.4 .71 \\
28.8 .71 \\
9.9 .71 \\
7.5 .71 \\
20.10 .71 \\
9.9 .71 \\
19.11 .71\end{array}$ & $\begin{array}{r}40 \\
40 \\
<10 \\
10 \\
320 \\
<10 \\
40 \\
160\end{array}$ & $\begin{array}{r}80 \\
80 \\
160 \\
160 \\
640 \\
40 \\
160 \\
320\end{array}$ & $\begin{array}{r}10 \\
10 \\
80 \\
80 \\
160 \\
10 \\
20 \\
160\end{array}$ & $\begin{array}{r}32 \\
32 \\
4 \\
4 \\
8 \\
<4 \\
<4 \\
<4\end{array}$ & $\begin{array}{r}128 \\
128 \\
8 \\
8 \\
64 \\
<4 \\
16 \\
16\end{array}$ & $\begin{array}{l}16 \\
16 \\
<4 \\
<4 \\
16 \\
<4 \\
<4 \\
<4\end{array}$ \\
\hline
\end{tabular}

Table II Antibodies in five patients to Poliovirus

\begin{tabular}{|c|c|c|c|c|}
\hline Patient & Date & $\begin{array}{l}\text { Neutralizing Antibody } \\
\text { Titres against Herpes- } \\
\text { virus hominis Type I }\end{array}$ & $\begin{array}{l}\text { Neutralizing Antibody } \\
\text { Titres against Herpes- } \\
\text { virus hominis Type II }\end{array}$ & $\begin{array}{l}\text { Complement-fixing } \\
\text { Antibodies against Herpzs- } \\
\text { virus hominis }\end{array}$ \\
\hline $\begin{array}{l}\text { F.S. } \\
\text { F.S. } \\
\text { M.P. } \\
\text { M.P. } \\
\text { J.M. } \\
\text { J.M. } \\
\text { M.G. } \\
\text { M.G. } \\
\text { M.S. } \\
\text { M.S. }\end{array}$ & $\begin{array}{r}11.7 .71 \\
20.7 .71 \\
4.8 .71 \\
12.8 .71 \\
13.7 .71 \\
21.7 .71 \\
23.1 .72 \\
13.2 .72 \\
10.4 .72 \\
9.5 .72\end{array}$ & $\begin{array}{r}40 \\
80 \\
<10 \\
<10 \\
<10 \\
10 \\
<10 \\
80 \\
<10 \\
160\end{array}$ & $\begin{array}{r}10 \\
20 \\
<10 \\
<10 \\
<10 \\
<10 \\
<10 \\
20 \\
<10 \\
40\end{array}$ & $\begin{array}{c}40 \\
160 \\
<10 \\
80 \\
<10 \\
320+ \\
<10 \\
640 \\
10 \\
320+\end{array}$ \\
\hline
\end{tabular}

Table III Antibodies in five patients to Herpesvirus hominis 
tion for diagnosis, the time-consuming nature of the test and its excessive demand for cell monolayers precludes its routine use in most virus laboratories.

Estimations of antibodies by complement-fixation and haemagglutination-inhibition methods do not usually include those elicited during enterovirus infections, because sufficiently specific antigens cannot be prepared. Pead (1971) has shown that serological investigations by these methods alone will result in a bias towards the diagnosis of respiratory virus disease. Neutralization becomes a necessity for the measurement of type specific enterovirus antibody response, for multiple cross-reactions occur when complement-fixing antigens are used. The Coxsackie virus type B5 complement-fixing antigen has been used in this laboratory to obtain useful serological information, but its ability to crossreact with all Coxsackie virus type B and some Echovirus antibodies has always been taken into account in the interpretation of results. In addition to providing confirmation of isolation results, the microneutralization test has enabled successful type-specific serological investigations of diseases caused by enteroviruses to be made in this laboratory, when isolation methods either proved negative or were not attempted. The technique has also been used for the differentiation of antibody response to Herpesvirus hominis types 1 and 2.

The method described in this paper requires little in reagents or technician time and is performed with materials which are readily available. No previous preparation of tubed monolayers is necessary. The serum/virus pre-incubation time and the dose of virus quoted are arbitrary.

References

Melnick, J. L., and Opton, E. M. (1956). Assay of poliomyelitis neutralising antibody in disposable plastic panels. Bull. Wld Hlth Org., 14, 129-146.

Moreau, P., and Furesz, J. (1967). A rapid micro tissue culture assay in BS-C-1 cells for the titration and neutralisation of measles virus. Canad. J. Microbiol., 13, 313-319.

Pead, P. J. (1971). Diagnostic virology in a routine laboratory, 1967 70. Community. Med., 126, 64-68.

Schmidt, N. J., Lennette, E. H., and Hanahoe, M. F. (1966). Microneutralisation test for the reoviruses. Application to detection and assay of antibodies in sera of laboratory animals. Proc. Soc. exp. Biol. (N.Y.), 121, 1268-1275.

Sever, J. L. (1962). Application of a microtechnique to viral serological investigations. J. Immunol., 88, 320-329. 